\title{
BUNAKA GYRINOIDES (BLEEKER, 1853) (PISCES: PERCIFORMES: ELEOTRIDAE), A NEW RECORD FROM KERALA
}

\author{
P. Thomas John ${ }^{1}$ and K.C. John ${ }^{2}$ \\ ${ }^{1}$ Department of Zoology, Catholicate College, Pathanamthitta, Kerala 689645, India. \\ ${ }^{2}$ School of Applied Life Sciences, M.G. University, Pathanamthitta, Kerala 689653, India.
}

web supplement

\begin{abstract}
Bunaka gyrinoides is recorded for the first time from Kerala in river Pamba at Perumthenaruvi, Kerala, India. It is characterised by metallic black colour, blue eyes, depressed head, oblique mouth, presence of ctenoid scales on the body, cycloid scales on the head and distinct paired pre-opercular canals. The fish is strictly adapted for benthic life and its occurrence in the river $300 \mathrm{~m}$ above $\mathrm{msl}$ and $120 \mathrm{~km}$ up from the sea has not so far been reported.
\end{abstract}

\section{KEYWORDS}

Bunaka gyrinoides, Eleotridae, Greenback Gauvina, India, Kerala, Pamba River, Perumthenaruvi

The family Eleotridae commonly known as sleepers (gudgeons) comprises nearly 150 species distributed among 35 genera (Nelson, 1994). Most of the species of this family are marine or estuarine (Larson \& Murdy, 2001) and enters fresh waters and ascend rivers far inland from the sea. Majority of them occur in tropical and subtropical areas and rarely in temperate waters. About 22 species of the family Eleotridae are known to occur in Indian waters (Koumans, 1941; Weber \& Beauforte, 1952) and seven visiting freshwaters (Jayaram, 1999). The genus Bunaka is represented by two species namely Bunaka gyrinoides and $B$. herwerdenii; the former being the species reported from India. This species was first recorded from Mangalore by Day (1878). Since then no account of this species has so far been published. Talwar and Jhingran (1991) remark that the fishes of the genus Bunaka Herre, though reported from several parts of Indo-west Pacific has not been found in the Indian waters. The present report deals with the detailed morphological description of B. gyrinoides based on four specimens collected from Pamba River at Perumthenaruvi.

\section{Methodology}

The specimens were collected during a detailed survey of the fish fauna of Pamba River at Perumthenaruvi, from the river pools $\left(76^{0} 50^{\prime}-76^{0} 55^{\prime} \mathrm{E} \& 9^{0} 20^{\prime}-9^{0} 25^{\prime} \mathrm{N}\right)$ for a period of 2 years from February 2001 to January 2003. The specimens were kept in $5 \%$ formalin after injecting the same into the viscera. Measurements were taken with an accuracy of $0.1 \mathrm{~mm}$ and counts of the fin and scales were noted. All other external characters were recorded.

\section{Bunaka gyrinoides (Bleeker, 1853)}

Eliotris canarensis Day, Fishes of India, 1878, P.313, pl.69. Fig. 2 - Fauna British India, Fishes 2, 1889, p.294.

Bunaka gyrinoides Koumans, Mem. Indian Mus. 1941, 13: 327.
Specimen collected: Four, 7.iii.2003, 145 -160mm SL, coll. Thomas John, det. K.C. John and Thomas John. Zoological Survey of India, Calicut, Reg. No.1446.

Description of the species: (Images 1-4 ${ }^{\mathrm{w}}$ ). D.Ivi; D21.8; A.I 8-9; P.18 L.I.55-60; Ltr.18-20; pre dorsal scales 30-35; height 4.8 - 5.0 in total length. Head pointed and depressed, 4-4.1 in total length. Eyes 5-6 in head length. Inter orbital one eye diameter or more.

Body anteriorly cylindrical, posteriorly compressed. Profile above the eye flat to slightly concave. The lower jaw is more prominent. Maxillary extends to the middle of the eye. The eyes are blue in live specimens. Teeth uniform, small and blunt, placed in several rows. Supra opercular groove distinct. Two pairs of longitudinal mucus canals present in the pre-opercle (Image $5^{\mathrm{w}}$ ). The tip of the tongue is emarginate. Scales small to medium in size; ctenoid on body, those of head nape and breast cycloid. Head scaled above from between the eyes, snout naked, cheek and opercle scaled. First dorsal fin obtuse, half as high as the body. The second dorsal fin and anal fin are a little higher than the first dorsal fin. Base of the pectoral fin scaled (Image $6^{\mathrm{w}}$ ). Pectoral fin is as long as the head without snout. Ventral fin is little shorter than the head.

The exposed part of each scale is dark. Fins especially the pectoral have an orange tinge and the fin-rays spotted with dark spots forming bands. The scales on the caudal peduncle show cteni arranged at the outer rim. The body scales are beset with many rows of cteni anteriorly, whereas those in the posterior part have fewer rows of cteni. The junction of the head and the body shows scales with few cteni and the head carries cycloid scales.

Colouration: The three specimens collected from February 2001 to January 2003 were preserved in $5 \%$ formalin and the colour description is based on these preserved specimens. However, in February 2003 another specimen similar to the one described here was obtained alive. This displayed a very strange and attractive colour pattern. The species had a straw coloured dorsal side, which was well demarcated from the lateral side with a number of closely packed black blotches. The ventral side was uniformly dark. This fish was held in captivity for 35 days and did not take any food offered and was unable to survive further. The morphometric details of this specimen agree well with that of the three specimens already examined. On death, the colouration of the fish changed very much. The prominent straw-white dorsal part of the body turned dark leaving only a slight trace of light shade so that one could hardly distinguish between the dorsal and lateral areas. 


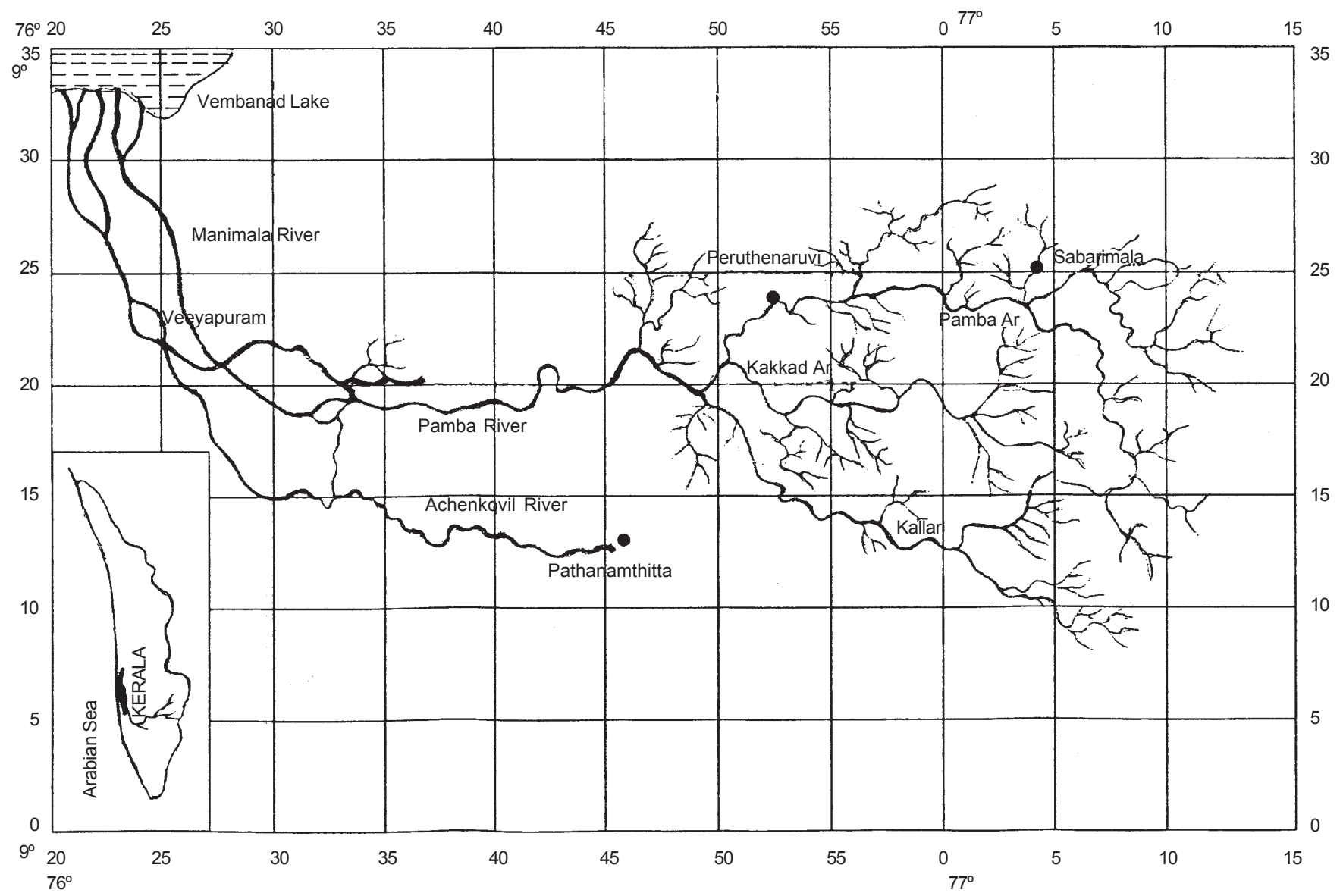

Figure 1. Map of Pamba River showing site of collection

Habitat: (Image $7^{\mathrm{w}}$ ). All the three specimens were collected from the bottom of the river pools in the Perumthenaruvi region above $300 \mathrm{~m}$ in the forest area. The pools have a depth of $8-12 \mathrm{~m}$ with rocky bottom.

\section{Discussion}

Bunaka gyrinoides is clearly distinguished from the other genera of Eleotridae by the absence of vomerine teeth; preopercle without spine; absence of bony crest on head; longitudinal scales numbering from 60 to 70 ; teeth on the upper jaw uniform, in many rows and two pairs of pre-opercular canals.

Day (1878) named the gobiid specimen collected from Mangalore as Eleotris canarensis. Koumans (1941) based on his studies on this specimen in the Indian Museum, Calcutta synonymised it with Eleotris gyrinoides Bleeker, which was subsequently placed under the genus Bunaka Herre.

The specimens obtained from Perumthenaruvi agree with the characters described by Weber and Beaufort (1952), however slight deviations exist in the following characters. The height of the body in total length is given as 6.5 by Day whereas the present specimens are deeper and the body depth is 4.8 to 5.0 in TL. The tip of the tongue is emarginate and not rounded as reported for this species. Weber and Beaufort refer to the presence of two or three mucous cheek canals but no reference about the origin and termination of the canals. Our observation reveals two pairs of distinct pre-opecular canals - a dorsal pair and a ventral pair. The dorsal canals start from the posteroventral part of the eye and extend up to the posterior end of the pre-opercle. The ventral canals originate from behind the midpart of the upper jaw and run backwards through the central region of the pre-opercle and terminate ahead of the posterior end of the opercle.

The part of the river from where the fish was collected shows abrupt habitat variation like swift water flow to rapids and then calm deep pools. This peculiarity is not met within any part of the river Pamba. This fish has not been reported from any part of Kerala so far. Its presence in this area of the river with rocks and boulders at the bottom is noteworthy. Studies of the piscine fauna of the Achenkovil and Pamba rivers by the second author for the past 20 years could never fetch Bunaka gyrinoides in any of the collections. Enquiries among the local fishermen revealed that they encountered this fish very rarely.

The scarcity of this species, peculiarities of its habitat, morphological adaptations for benthic life and the paucity of literature generate interest in further studies. Detailed investigations are being carried out by the authors in this line. 


\section{REFERENCES}

Day, F. (1878). The Fishes of India, being a Natural History of the Fishes known to Inhabit Seas and Fresh Waters of India, Burma and Ceylon. Vol. I, 313pp.

Jayaram, K.C. (1999). The Freshwater Fishes of the Indian Region. Narendra Publishing House, Delhi, India, 551pp.

Koumans, F.P. (1941). Gobioid Fishes of India. Memoirs of the Indian Museum 13, 327pp.

Larson, H.K. and E.O. Murdy (2001). FAO species identification guide for Fishery purpose. The living marine resources of the Western Central Pacific. Vol.6, 374-377pp.

Nelson, J.S. (1994). Fishes of the World, $3^{\text {rd }}$ Edition. John Wiley and Sons, Inc., New York, 600pp.

Talwar, P.K and A.G. Jhingran (1991). Inland Fishes of India and Adjacent Countries. Oxford \& IBH Publishing Co. Pvt. Ltd. New Delhi.

Weber, M. and L.F. de Beaufort (1952). The Fishes of the Indo Australian Archipilago, X. Gobioidea. E.J. Brill, Leiden, xiii+423pp.

\section{ACKNOWLEDGEMENT}

The authors are grateful to the Directors, Zoological Survey of India Chennai and Kozhikode, for allowing us to consult the scientists in this work. Our sincere thanks are due to Dr. K. Rema Devi, Scientist 'C', Southern Regional Station, Chennai for confirming the identity of the fish and correcting the manuscript. We thank Shri. K.G. Padmanabhan for suggesting the problem and periodical advice. Dr. A. Chandran and Dr. Thomas George, School of Applied Life Sciences, M.G. University have helped a lot in this work.

${ }^{w}$ See Images 1-7 on the web at www.zoosprint.org

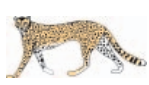

\section{RABIES IN AN INDIAN RHINOCEROS (RHINOCEROS UNICORNIS) IN CAPTIVITY}

\section{T. Rahman, D.C. Pathak and K.L. Jamir}

Department of Pathology, College of Veterinary Science, Assam Agricultural University, Khanapara, Guwahati, Assam 781022, India

Rabies is a highly fatal zoonotic viral encephalitis to which almost all warm-blooded animals including those living in wild and humans are susceptible. The disease is most commonly seen in carnivores from which it is transmitted to herbivores. Reports on occurrence of rabies in Indian Rhinoceros are very few (Das, 1968; Mukherjee et al., 1984; Sabharwal, 1992; Selvam et al., 2003). The present communication is to keep on record the clinical signs and pathology of rabies in an Indian Onehorned Rhinoceros in captivity.

A female Rhino of 4 years 7 months old died in the Assam State Zoo after showing nervous disorders for about 36 hours. The clinical signs exhibited by the animal were: off-feed, excitement, repeated falling and rolling on the ground, ramming of head on the ground, staggering gait and shivering of hind quarter. There was severe congestion of eyes, epistaxis and bleeding from mouth due to injury, and prolapse of rectum. As reported, the animal preferred to drink and stay in water. On enquiry, it was revealed that a stray dog was noticed about a week ago in the neighbouring enclosure. Haematological examination viz. TLC, TEC, DLC and haemoglobin were found within the normal range.

Postmortem examination showed congestion of brain with clotted blood in the cranial cavity. The nasal mucosa was congested and nasal cavities were filled with clotted blood. Muscles in the head region were haemorrhagic. These changes were mostly due to injury meted to the animal during the period of excitement. Tongue and oral cavity showed hyperemia. Stomach and intestine contained half digested feed materials. Representative tissue samples including brain were collected in $10 \%$ formol-saline and processed through paraffin embedding technique and sections were stained by routine haematoxylin and eosin method for histopathological studies.

Microscopically, section of brain showed lesions of encephalitis characterized by congestion and perivascular cuffing by lymphocytes and gliosis. The purkinjee cells of cerebellum revealed single to multiple eosinophilic intracytoplasmic inclusion bodies with distinct haloes around. Almost similar clinical signs of exicitability, gross and microscopic lesions were described by Mukherjee et al. (1984) in case of rabies in a captive rhinoceros. The stray dog might have acted as the source of the disease, although no bite injury could be seen during postmortem examination of the animal. However, demonstration of intracytoplasmic inclusion bodies suggestive of Negri bodies confirmed the disease as rabies.

\section{REFERENCES}

Das, M.S. (1968). A note on some aspects of viral zoonoses. National Seminar on Zoonoses in India, 9-16 October, 1968 held in National Institute of Communicable Diseases, Delhi (India).

Mukherjee, S.C., R.K. Das, B.M. Arora and M.L. Mehrotra (1984). A case of rabies in a captive Rhinoceros (R. unicornis). Indian Journal of Comp. Microbiological and Immunological Infectious Diseases 5(1): 32 .

Sabharwal, D.N. (1992). Cited by Arora, B.M. (1994). Infectious and parasitic diseases of mammals, reptiles and amphibians. In: Arora, B.M. (editor). Wildlife Diseases in India, $1^{\text {st }}$ edition. Periodical Expert Book Agency, New Delhi.

Selvam, P.N., R.S. Rawat and B.S. Bonal (2003). Rabies in Rhino at National Zoological Park, New Delhi - A case report. Zoos' Print 18(10): $13-14$. 